(1893). He also translated Hermann's "Elements of Human Physiology" (1875). In 1902 he visited the United States by invitation to inspect the physiological laboratories there, and in the same year delivered the Croonian Lecture before the Royal Society on "Certain Chemical and Physiological Properties of Hæmoglobin". He died on March 29, 1909 ; a portrait and bibliography will be found in the Lancet, 1, 1141 (1909).

\section{Sir Richard Thorne Thorne (I84I-I899)}

Sir Richard Thorne Thorne, F.R.S., a notable hygienist of the Victorian era, was born on October 13, 1841, at Leamington, Warwickshire, the son of a banker. He received his early education at Neuwied in Prussia and at a Paris lycée, and his medical training at St. Bartholomew's Hospital, where he qualified in 1863. Eventually he was elected physician to the Royal Hospital for Diseases of the Chest and to the London Fever Hospital, and about this time he was employed by the Medical Department of the Local Government Board to make various reports. He first became widely known by his work on quarantine and the international relations for the prevention of the spread of disease from one country to another. From 1885 onward he attended many international sanitary congresses as a representative of the British Government, and in 1892 he succeeded Sir George Buchanan as principal medical officer of the Local Government Board. The subjects in which he was most interested were diphtheria, on the natural history and prevention of which he delivered the Milroy Lectures before the Royal College of Physicians in 1891 ; tuberculosis, the administrative control of which formed the subject of his Harben Lectures in 1899, and the establishment of isolation hospitals for infectious diseases. He was elected a fellow of the Royal Society in 1890 and was also an honorary member of the Royal Academy of Medicine of Rome and a foreign associate of the French Society of Hygiene. His death took place suddenly on December 18, 1899.

\section{Recent Earthquake}

A SEvErE earthquake shook Quetta and the surrounding country in Baluchistan at 8.4 a.m. local time (2.34 a.m., G.м.т.) on September 29, 1941. The shock was also felt, though less distinctly, at Sibi, Mach, and Chaman, all in Baluchistan. The shock, which lasted according to human perception for thirty-five seconds at Quetta, was accompanied by heavy rumbling, and caused considerable apprehension. Although telephone and telegraph communications were temporarily dislocated, no serious damage or casualties are reported, and railways were unaffected. This lack of damage might easily be due to the thorough building of the new city after the calamitous earthquakes of May 31 and June 2, 1935. The re-planned city was built to earthquake-proof design according to the best building codes of California as worked out by seismologists and engineers. After-shocks to the 1941 earthquake took place at 2.35 a.m., 2.54 a.m., 4.34 a.m., 5.4 a.m. and
8 p.m. (all G.M.T.) on the same day. It will be recalled that Quetta was levelled to the ground on May 31, 1935, and that an area approximately a hundred miles in diameter was devastated. A severe after. shock occurred on June 2, 1935, and altogether there were about 40,000 casualties (NATURE, June 15,1935 , p. 986 and several subsequent numbers). Severe shocks also occurred near Quetta in September and October 1937.

On September 29 at just after 5 p.m. G.M.T. an earth tremor of some severity rattled crockery and moved furniture at Bethesda, a town of some five thousand inhabitants in Wales. The shock, which lasted according to human perception for about three seconds, did not cause any serious damage or casualties. Two earlier tremors of less intensity occurred early on the morning of September 27. Earth shakes, probably due to mining subsidences and minor fault slips, occur fairly frequently in Wales. One such happened at Pwllheli on December 12, 1940 (NATURE, Dec. 21, 1940, p. 803).

\section{Announcements}

M. MaIsky, the Soviet Ambassador, has been offered and has accepted honorary membership of the Athenæum.

The title of Sir Ernest Cassel reader in commerce in the University of London has been conferred on Dr. Vera Anstey, in respect of the post held by her in the London School of Economics.

Dr. Frederic John Nattrass, lecturer in therapeutics and clinical teacher in medicine in King's College, Newcastle-upon-Tyne (University of Durham) has been appointed professor of medicine in the College.

The Minister without Portfolio has appointed an Inter-Departmental Committee, under the chairmanship of Lieutenant-Colonel Sir Francis Shelmerdine, director-general of civil aviation, to make recommendations as regards the reconstruction, organization and development of civil aviation after the War.

THE fourth Hinchley Memorial Lecture of the Institution of Chemical Engineers will be delivered by Sir Richard Gregory, who will speak on "Scientific Knowledge and Action". The address will be given in the Institution of Civil Engineers on October 24 at 2.30 p.m.

The autumn meeting of the National Academy of Sciences of the United States will be held at the University of Wisconsin during October 13-15.

Prof. W. E. S. Turner, professor of glass technology in the University of Sheffield, will deliver a lecture before the London Section of the Society of Glass Technology on "Glass as a Substitute Material" on October 15 at 4.30 . The meeting will be held at the Electric Lamp Manufacturers' Association, 2 Savoy Hill, London, W.C.2. 